\section{The new concussion in sport guidelines are here. But how do we get them out there?}

\author{
Caroline F Finch, Peta White
}

The 2016 Consensus Statement on Concussion in Sport has recently been published in BJSM, as the major conduit for informing sports medicine practitioners and clinicians worldwide about the importance of this condition, its assessment and management. ${ }^{1}$ This information dissemination strategy has worked well for previous concussion statements and has certainly raised the profile of the issue in sports medicine circles. ${ }^{2}$

\section{SUCCESSFUL DISSEMINATION OF GUIDELINES NEEDS TO CONSIDER THE} RELEVANT IMPLEMENTATION CONTEXT

But publishing guidelines only in sports medicine journals means they only reach a particular target group, especially if no consideration is given to implementation and dissemination strategies more widely. $^{2}$ There is no doubt that sports medicine practitioners should be one of the major target groups for this information, but there are many other stakeholder groups (eg, coaches ${ }^{3}$ ) that are overlooked with this approach. Ensuring effective and sustained sports safety actions across all levels of sport, such as concussion guideline adoption, requires recognition of the ecological context in which sport is delivered, how participation is undertaken and the range of both professional and volunteers who support them. ${ }^{4}$ The implementation role of the key stakeholders at each ecological level of concussion guideline implementation is shown in table 1 .

The principles behind optimal knowledge transfer for concussion guidelines and education internationally has previously been discussed in the BJSM. ${ }^{5}$ To our knowledge, the preferred specific information sources for concussion knowledge have not been summarised. We draw on our experiences within a community (or recreational) sport delivery setting that

Australian Centre for Research into Injury in Sport andits Prevention (ACRISP), Federation University Australia, Ballarat, Victoria, Australia

Correspondence to Professor Caroline F Finch, Australian Centre for Research into Injury in Sport and its Prevention (ACRISP), Federation University Australia, Ballarat, Victoria, Australia; c.finch@federation.edu.au is common in many parts of the world to give suggestions for which organisations and/or professional groups should be the delivery agent/producer of such information.

\section{HOW DO PLAYERS AND PARENTS WANT TO BE INFORMED ABOUT CONCUSSION?}

In the setting of community-wide Australian football participation, we have previously reported that both players ${ }^{6}$ and parents of junior players ${ }^{7}$ have limited awareness of concussion guidelines and have concerns about their ready application in community sport. These perceptions lead to the natural conclusion that both players and parents need to be better informed and educated about all aspects of concussion guidelines. Importantly, this cannot be achieved through papers published in peer-review journals and specific dissemination strategies would be needed for this.
As part of our discussions with both stakeholder groups, ${ }^{67}$ we asked them about their preferred sources of concussion information. As shown in tables 2 and 3, no one said 'a medical journal'.

\section{HOW DO DOCTORS WANT TO BE INFORMED?}

Given the importance of doctors, both as the recognised expert responsible for actioning concussion guidelines mentioned in the Consensus Statement ${ }^{1}$ and as an important and preferred source of information recognised by both players and parents, ${ }^{67}$ we surveyed general practitioners about their concussion knowledge and their preferred sources of information. ${ }^{8}$ As shown in table 4, none indicated 'peer-review medical journal' as a major concussion information source. Moreover, the vast majority of preferred sources were not linked to organisations or professionals most commonly directly associated with sport and its delivery-they wanted to get their information from recognised medical and medical education sources.

\section{BRING IN THE SOCIAL MARKETING EXPERTS}

A recent study $^{9}$ has stressed the need to involve stakeholders 'from the outset to

Table 1 The ecological context (and hierarchical levels) of implementation of concussion guidelines in community, or recreational, sport*

\begin{tabular}{|c|c|}
\hline $\begin{array}{l}\text { Ecological (or hierarchical) } \\
\text { level of sports safety } \\
\text { implementation }\end{array}$ & Implementation role \\
\hline Players and parents of players & $\begin{array}{l}\text { Target end users and beneficiaries of concussion education, guidelines and } \\
\text { prevention; actions would be at both the individual and whole-of-team level }\end{array}$ \\
\hline \multicolumn{2}{|l|}{$\downarrow$} \\
\hline Coaches and sports trainers & $\begin{array}{l}\text { Key community sports personnel to initially recognise a potential concussion has } \\
\text { occurred, initiate local actions in response to the suspected/actual concussion, } \\
\text { support and monitor the adoption of guidelines and support players diagnosed } \\
\text { with concussion return to play }\end{array}$ \\
\hline \multicolumn{2}{|l|}{$\downarrow$} \\
\hline General practitioners (doctors) & $\begin{array}{l}\text { Key role in diagnosing concussion and providing medical management of } \\
\text { concussion. (In most community sport settings, it would not be common for sports } \\
\text { physicians or sports physiotherapists to be associated with teams, so access to } \\
\text { general medical personnel is necessary.) }\end{array}$ \\
\hline \multicolumn{2}{|r|}{ 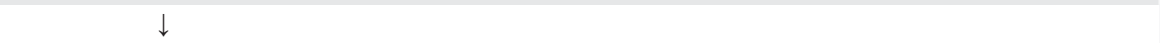 } \\
\hline $\begin{array}{l}\text { Sports bodies (regional, national } \\
\text { and/or international) and peak } \\
\text { sports medicine/health promotion } \\
\text { agencies }\end{array}$ & $\begin{array}{l}\text { Setting of rule, preparation and dissemination of guideline information and other } \\
\text { resources, supporting community sport infrastructure, education }\end{array}$ \\
\hline \multicolumn{2}{|l|}{$\downarrow$} \\
\hline International expert opinion & $\begin{array}{l}\text { Determining, summarising, publishing and disseminating the scientific and } \\
\text { medical content of concussion guidelines }\end{array}$ \\
\hline $\begin{array}{l}{ }^{*} \text { This table describes the situation } \\
\text { through community-based or recre } \\
\text { USA, have sports delivery systems } t \\
\text { some of the opportunities for inter } \\
\text { trainers who would be a key condu }\end{array}$ & $\begin{array}{l}\text { for countries where most sporting participation opportunities are provided } \\
\text { ational sporting organisations. It is acknowledged that some countries, like the } \\
\text { that are more likely to be linked to high schools or university colleges and so } \\
\text { vention may be different. In particular, US-based sports have certified athletic } \\
\text { uit of concussion knowledge and action. }\end{array}$ \\
\hline
\end{tabular}


Table 2 Australian football players' preferred sources of concussion information (listed in terms of decreasing importance)*

Organisation or professionals who should be responsible for disseminating concussion information and resources of the preferred types

\begin{tabular}{|c|c|c|c|c|c|}
\hline Preferences & Coaches/sports trainerst & Medical doctors $\ddagger$ & Clubs/associations & Lead sport body§ & $\begin{array}{l}\text { Peak sports medicine } \\
\text { agency } 1\end{array}$ \\
\hline Clubs/coaches and trainers/league officials & $\checkmark$ & & $\checkmark$ & & \\
\hline $\begin{array}{l}\text { Seminars/information sessions at the start of } \\
\text { season involving all players/teams/clubs }\end{array}$ & $\checkmark$ & & $\checkmark$ & $\checkmark$ & \\
\hline $\begin{array}{l}\text { Posters displayed in club rooms, change } \\
\text { rooms, etc. }\end{array}$ & & & $\checkmark$ & $\checkmark$ & $\checkmark$ \\
\hline $\begin{array}{l}\text { Players who have previously been concussed } \\
\text { to share their experiences }\end{array}$ & $\checkmark$ & $\checkmark$ & & & \\
\hline $\begin{array}{l}\text { Doctors/hospitals (interestingly, they } \\
\text { also doubt the expertise of most medical } \\
\text { practitioners in relation to concussion }{ }^{7} \text { ) }\end{array}$ & & $\checkmark$ & & & \\
\hline Hardcopy documents & $\checkmark$ & & $\checkmark$ & & \\
\hline Mass/social media & & & & $\checkmark$ & $\checkmark$ \\
\hline \multicolumn{6}{|c|}{$\begin{array}{l}\text { *Information obtained during three focus groups as reported in White et al. }{ }^{6} \\
\text { †In Australia, sports trainers are trained volunteers providing sports first aid and initial injury assessment at the sports sideline. } \\
\text { †In community sport, it is unusual to have a sports doctor attached to sports teams so this would be a doctor with generalist medical qualifications only. In the US sporting } \\
\text { system, this role may be filled by certified athletic trainers. } \\
\text { §In our work, this would be the Australian Football League. International equivalents would be FIFA, World Rugby Union, etc. } \\
\text { ๆIn Australia, this would be Sports Medicine Australia. International equivalents are the American College of Sports Medicine, British Association of Sport and Exercise Medicine, } \\
\text { South African Sports Medicine Association, etc. }\end{array}$} \\
\hline
\end{tabular}

ensure the incorporation of sport-specific contextual influence that will increase the potential for wide-scale adoption and scale-up of preventive research findings'. As our findings show, the avenues for sports injury information dissemination preferred by these stakeholders are quite different to what is of most relevance to sports medicine practitioners; none are publications in peer-reviewed journals. Importantly, communicating with the broader medical community about concussion will require the sports medicine sector to first engage more directly with general medical education and update avenues, as doctors are unlikely to readily recognise new information sources disseminated through sport-specific channels. So while disseminating information about concussion through local/national/international sports bodies might reach players and their parents, it will not reach the general community-based medical profession.

We are fortunate to now have expertagreed, evidence-based statements to guide the management and detection of concussion. ${ }^{1}$ But this information will only reach and also be adopted by all stakeholders if targeted disseminated strategies are used and the learnings from social marketing are now applied. ${ }^{2}$ New approaches to information dissemination that engage the range of organisations and practitioner groups, including intermediary agencies such as peak agencies ${ }^{10}$ must be the focus of concussion prevention and management efforts going forward.

\section{Twitter@CarolineFinch}

Contributors CFF led the writing of this item and was the Chief Investigator of the funded project that underpinned this work. PW was the Project Manager and had oversight of all of the data collection activities

Table 3 Parents' (of junior Australian football players) preferred sources of concussion information (listed in terms of decreasing importance) ${ }^{\star}$ Organisation or professionals who should be responsible for disseminating concussion information and resources of the preferred types

\begin{tabular}{|c|c|c|c|c|c|}
\hline Preferences & Coaches/sports trainers $t$ & Medical doctors $\ddagger$ & Clubs/associations & Lead sport body§ & $\begin{array}{l}\text { Peak sports medicine } \\
\text { agencyๆ }\end{array}$ \\
\hline Posters/DVD & & & $\checkmark$ & $\checkmark$ & $\checkmark$ \\
\hline Seminars/training sessions & & & $\checkmark$ & $\checkmark$ & $\checkmark$ \\
\hline $\begin{array}{l}\text { Directly from (non-medical) professionals } \\
\text { associated }\end{array}$ & $\checkmark$ & & $\checkmark$ & & \\
\hline Level 1 sports trainer course ${ }^{* *}$ & & & & & $\checkmark$ \\
\hline Doctors/emergency departments & & $\checkmark$ & & & \\
\hline League website/code of conduct & & & $\checkmark$ & $\checkmark$ & \\
\hline Mass/social media & & & & $\checkmark$ & $\checkmark$ \\
\hline \multicolumn{6}{|c|}{$\begin{array}{l}\text { *Information obtained during two focus groups as reported in White et al. }{ }^{7} \\
\text { †In Australia, sports trainers are trained volunteers providing sports first aid and initial injury assessment at the sports sideline. } \\
\text { †ln community sport, it is unusual to have a sports doctor attached to sports teams so this would be a/doctor with generalist medical qualifications only. In the US sporting } \\
\text { system, this role may be filled by certified athletic trainers. } \\
\text { §In our work, this would be the Australian Football League. International equivalents would be FIFA, World Rugby Union, etc. } \\
\text { IIn Australia, this would be Sports Medicine Australia. International equivalents are the American College of Sports Medicine, British Association of Sport and Exercise Medicine, } \\
\text { South African Sports Medicine Association, etc. } \\
\text { ** In Australia, this is delivered by Sports Medicine Australia and other accredited providers. }\end{array}$} \\
\hline
\end{tabular}


Table 4 General practitioners' preferred sources of information about concussion*

\begin{tabular}{|c|c|c|c|c|c|c|}
\hline \multirow[b]{2}{*}{ Preferences } & \multicolumn{6}{|c|}{$\begin{array}{l}\text { Organisation or professionals who should be responsible for disseminating concussion information and resources of } \\
\text { the preferred types }\end{array}$} \\
\hline & Players/parents & Coaches/trainers & Sports club/association & $\begin{array}{l}\text { Peak sport } \\
\text { body }\end{array}$ & $\begin{array}{l}\text { Lead sports } \\
\text { medicine agency }\end{array}$ & $\begin{array}{l}\text { Lead medical } \\
\text { authority (general) }\end{array}$ \\
\hline $\begin{array}{l}\text { Continuing medical education course/ } \\
\text { conferences }\end{array}$ & & & & & & $\checkmark$ \\
\hline Consultations with specialists & & & & & $\checkmark$ & $\checkmark$ \\
\hline Consulting with colleagues & & & & & & $\checkmark$ \\
\hline $\begin{array}{l}\text { Australian College of Sports and Exercise } \\
\text { Physicians (ACSEP) }\end{array}$ & & & & & & $\checkmark$ \\
\hline Conferences/seminars/dinners & & & & & & $\checkmark$ \\
\hline Sports Medicine Australia & & & & & $\checkmark$ & \\
\hline Training in medical school or residency & & & & & & $\checkmark$ \\
\hline $\begin{array}{l}\text { Websites (eg, Think First, Centre for Disease } \\
\text { Control) }\end{array}$ & & & & & $\checkmark$ & $\checkmark$ \\
\hline Social network/media & & & & & $\checkmark$ & $\checkmark$ \\
\hline
\end{tabular}

that generated the data reported here. Both contributed to the witting of the paper

Funding This work was funded by a Victorian Sports Injury Prevention Research Grant through the Department of Planning and Community Development, Sport and Recreation Victoria.

Competing interests None declared.

Ethics approval Monash University Human Ethics Committee.

Provenance and peer review Not commissioned; externally peer reviewed.

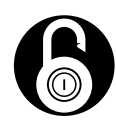

\section{OPEN ACCESS}

Open Access This is an Open Access article distributed in accordance with the Creative Commons Attribution Non Commercial (CC BY-NC 4.0) license, which permits others to distribute, remix, adapt, build upon this work non-commercially, and license their derivative works on different terms, provided the original work is properly cited and the use is non-commercial. See: http:// creativecommons.org/licenses/by-nc/4.0/

(C) Article author(s) (or their employer(s) unless otherwise stated in the text of the article) 2017. All rights reserved. No commercial use is permitted unless otherwise expressly granted.

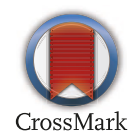

To cite Finch CF, White P. Br J Sports Med 2017;51:1734-1736.

Received 21 June 2017

Revised 14 August 2017

Accepted 15 August 2017

Published Online First 22 September 2017

Br J Sports Med 2017;51:1734-1736.

doi:10.1136/bjsports-2017-098212

\section{REFERENCES}

1 McCrory P, Meeuwisse W, Dvořák J, et al. Consensus statement on concussion in sport- - the 5th international conference on concussion in sport held in Berlin, October 2016. Br J Sports Med;2017:838-47.

2 Finch CF, McCrory P, Ewing MT, et al. Concussion guidelines need to move from only expert content to also include implementation and dissemination strategies. Br J Sports Med 2013;47:12-14.

3 Stoszkowski J, Collins D. Sources, topics and use of knowledge by coaches. J Sports Sci 2016;34:794-802.
4 Finch CF, Donaldson A. A sports setting matrix for understanding the implementation context for community sport. Br J Sports Med 2010;44:973-8.

5 Provvidenza C, Engebretsen L, Tator C, et al. From consensus to action: knowledge transfer, education and influencing policy on sports concussion. $\mathrm{Br}$ J Sports Med 2013;47:332-8.

6 White PE, Donaldson A, Sullivan SJ, et al. Australian Football League concussion guidelines: what do community players think? BMJ Open Sport Exerc Med 2016;2:e000169.

7 White PE, Register-Mihalik J, Donaldson A, et al. Concussion guideline implementation perceptions and experiences among parents of community-level Australian Football junior players. BMJ Open Sport Exerc Med 2017;3:e000215.

8 Donaldson A, Newton J, McCrory P, et al. Translating guidelines for the diagnosis and management of sports-related concussion into practice. Am J Lifestyle Med 2016;10:120-35.

9 Finch CF, Talpey S, Bradshaw A, et al. Research priorities of international sporting federations and the IOC research centres. BMJ Open Sport Exerc Med 2016;2:e000168.

10 Bekker S, Paliadelis P, Finch CF. The translation of sports injury prevention and safety promotion knowledge: insights from key intermediary organisations. Health Res Policy Syst 2017;15:25. 